\title{
Evaluation of the Effect of Incorporation of Functional Ingredients on the Shelf Life of Chicken Patties Using Different Packaging Conditions during Frozen Storage
}

\author{
Shruti Sharma*, Himanshu Prabhakar, S.S. Thind, Manish Chatli and Amarjeet Kaur \\ Food Science \& Technology Department, Punjab Agricultural University, \\ Ludhiana, Punjab-141001, India \\ *Corresponding author
}

\begin{tabular}{|c|c|}
\hline & A B S T R A C T \\
\hline Keywords & \multirow{5}{*}{$\begin{array}{l}\text { The objective of the study was to evaluate the quality and frozen storage shelf life } \\
\text { of chicken patties incorporated with functional ingredients like dried apricots and } \\
\text { dried citrus fruit residue. Dried apricots }(2 \%) \text { and dried citrus fruit residue }(1 \%) \\
\text { were incorporated in chicken patties, which were packed (conventionally and } \\
\text { under vacuum) in LDPE and PP/PE co-extruded laminate bags and frozen stored } \\
\left(-20 \pm 2{ }^{\circ} \mathrm{C}\right) \text { for two months. It was observed that vacuum packed chicken patties } \\
\text { had significantly ( } \leq \leq 0.5) \text { lower moisture, ash, fat, protein, crude fiber, sensory } \\
\text { attributes, lower free fatty acids, peroxide values and thiobarbituric acid values. } \\
\text { Also, vacuum packed chicken patties had significantly }(\mathrm{p} \leq 0.5) \text { lower free fatty } \\
\text { acids, peroxide values and thiobarbituric acid values than conventionally packed } \\
\text { chicken patties at the end of two months of frozen storage }\left(-20 \pm 2^{\circ} \mathrm{C}\right) \text { period. }\end{array}$} \\
\hline & \\
\hline $\begin{array}{l}\text { fruit residue, Vacuum } \\
\text { packaging, Frozen } \\
\text { storage. }\end{array}$ & \\
\hline Article & \\
\hline $\begin{array}{l}\text { Accepted: } \\
\text { 20 September } 2017 \\
\text { Available Online: } \\
\text { 10 November } 2017\end{array}$ & \\
\hline
\end{tabular}

\section{Introduction}

India has one of the world's largest and fastest growing poultry industry and is among the top five chicken meat producing countries in the world (MOSPI 2015). The total poultry population in the country was 729.2 million in 2012 (Livestock census 2012). The broiler production is growing as a rate of nearly 8-10 per cent every year. The poultry/chicken meat production in the country increased from 0.12 million metric tonnes in 1981 to 2.2 million metric tonnes in 2011 (Archive India 2011). Total meat production in India is about 6.23 million metric tonnes and total poultry meat production is 2.21 million metric tonnes per annum thus, poultry meat constitutes 37 per cent of the total meat production in the country (FAOSTAT, 2013). Per capita consumption of meat products has grown from 870 grams in 2000 to about 1.68 kilograms in 2005. Punjab has one of the largest (16.8 million) poultry population among the Indian states and is also a major consumer of poultry meat products (Livestock census, 2012). Also, Punjab contributes to 3.6 per cent of the total meat production of India. Some prominent players in poultry processing industry like Al-chemist, Sagari Foods, Godrej Agrovet, Chatha Foods, Suguna Foods etc. have set up state of art poultry processing units with forward and backward linkages in 
the region, offering great scope for processed chicken meat products. Consumption of meat and its products is steadily increasing in the country. In meat and meat processing sector, poultry meat has been the fastest growing segment in India (National Meat and Poultry Processing Board, 2014). Chicken meat is the most widely accepted meat in India, unlike beef or pork; it does not have any religious restrictions and taboos against its consumption. Functional foods are defined as: Foods, which by virtue of physiologically active food components, provide health benefits beyond basic nutrition by the International Life Sciences Institute (ILSI). The need for developing functional food products as per the demands of health conscious consumers requires the meat product manufacturing sector to introduce innovative processing systems. Incorporation of functional ingredients in the recipes of the comminuted meat products is one approach for the development of functional meat products. $\beta$-carotene is one of the most important functional ingredients for development of value added meat products because of its efficacy in providing vitamin A activity from vegetable sources in the human food supply. The processed meat products are fat and protein dense but deficient in complex carbohydrates such as dietary fiber that is associated with numerous health benefits. The addition of citrus fruit fiber in the form of dried residue of kinnow orange fruit after juice extraction may address the proposition of enhancing the functional properties of chicken patties.

\section{Material and Methods}

\section{Raw material}

The chicken carcasses were procured from the Department of Livestock Production and Management, Guru Angad Dev Veterinary and Animal Science University, Ludhiana.
After procurement, the dressed birds were washed, deboned, packed in polyethylene bags and frozen stored at $-20 \pm 2^{\circ} \mathrm{C}$ in deep freezer, till its further use. The frozen chicken meat was taken out and thawed overnight in the refrigerator at $4 \pm 1{ }^{\circ} \mathrm{C}$. Then, it was minced using meat mincer (ESKIMO grinder, MEW 714-H82, MADO GmbH, Dornharn, Germany) by passing through $4 \mathrm{~mm}$ sieve.

The ground meat was used for the preparation of the patties. Whole dried apricots were procured from the local market, the seeds were removed and size reduced to granular form in food processor (Inalsa, Max Plus) and stored in PET jars. The citrus fruit (kinnow) was procured from the local market, its juice was extracted and the residue so obtained was subjected to drying at $55 \pm 2^{\circ} \mathrm{C}$ for 48 hours using tray drier. The dried residue was size reduced to form powder in food processor (Inalsa, Max Plus) and stored in PET jars.

\section{Packaging material}

Low Density Polyethylene bags (LDPE 100 gauge) and Polypropylene/Polyethylene (PP/PE) laminates were used for conventional and vacuum packaging of chicken patties respectively, for storage studies.

\section{Proximate composition and chemical parameters}

Proximate composition was determined by the following methods (AOAC, 1995).

\section{Moisture}

Minced sample (5 g) was dried in a clean, dry and pre-weighed aluminium moisture dish and kept in hot air oven with lid removed at $100-105^{\circ} \mathrm{C}$ for $16-18$ hours. After cooling in desiccators, loss in weight was calculated as moisture of sample and expressed as per cent moisture. 
Weight of fresh sample $(\mathrm{g})$ -

Weight of dried sample (g)

Moisture $(\%)=$

Weight of fresh sample (g)

\section{Protein}

The protein content was determined using automatic digestion and distillation unit (KelPlus-KES 12L, Pelican Industries, Chennai). Pre-weighed moisture free samples were digested in the tubes using $10 \mathrm{ml}$ conc. sulphuric acid and digestion mixture (copper sulphate and potassium sulphate in 1:10 ratio) till light green colour appeared. Distillation was performed in the automatic distillation unit. Ammonia released by distillation of digested sample with saturated $\mathrm{NaOH}(80 \mathrm{ml})$ was captured in $0.1 \mathrm{~N}$ HCL to calculate per cent nitrogen $\left(\mathrm{N}_{2}\right)$. A parallel blank was run to eliminate the error. The per cent nitrogen was converted into per cent protein as:

Nitrogen $(\%)=\frac{14.01 \times 0.1 \times(\mathrm{BV}-\mathrm{TV})}{\mathrm{W} \times 1000} \times 10$

Protein $(\%)=\%$ nitrogen $\times 6.25$

BV: Titre value of blank

TV: Titre value of sample

$\mathrm{W}$ : sample weight $(\mathrm{g})$

Fat

Fat content was estimated using Socs Plus (SCS-6-AS, Pelican Industries, Chennai). Moisture free sample was taken in an extraction thimble fitted in a specially designed beaker. Around $80 \mathrm{ml}$ petroleum ether was added to the beaker and extraction was carried out using 5 segment programme. After the process was over, the beakers containing residual fat were placed in hot air oven $\left(100^{\circ} \mathrm{C}\right)$ for $20-30$ minutes. Thereafter, beakers were removed and cooled in a desiccator. Fat percentage in the sample was calculated using the following formula:

$$
\text { Fat }(\%)=\frac{\text { Weight of fat }(\mathrm{g})}{\text { Weight of sample }(\mathrm{g})} \times 100
$$

\section{Ash}

Ash content was determined by placing the charred samples in silica dishes and heated in muffle furnace at $525^{\circ} \mathrm{C}$ for $6 \mathrm{hrs}$ until white coloured ash was obtained to a constant weight.

$$
\operatorname{Ash}(\%)=\frac{\text { Weight of ash }(\mathrm{g})}{\text { Weight of sample }(\mathrm{g})}
$$

\section{Crude fiber}

Ten gram of sample was digested with $200 \mathrm{ml}$ of boiling $0.225 \mathrm{~N}$ Sulphuric acid in heating mantle for 30 minutes with condenser. After boiling, the contents were filtered in the fluted funnel and washed with boiling water to free from acids. This was then boiled with preheated $200 \mathrm{ml}$ of $0.313 \mathrm{~N} \mathrm{NaOH}$ for 30 minutes in heating mantle with condenser. The sample was then filtered and washed in fluted funnel. The material was dried, weighed and then ashed in the furnace at $540^{\circ} \mathrm{C}$. Subtraction of ash weight from weight of acid, alkali treated sample give weight of crude fiber.

Crude fiber $(\%)=\frac{\text { Weight of crude fiber }}{\text { Weight of sample taken }} \times 100$

\section{Peroxide value}

The peroxide value was measured as per procedure described by Koniecko (1979) with suitable modifications. $5 \mathrm{~g}$ sample was blended with $30 \mathrm{ml}$ chloroform for $2 \mathrm{~min}$. in 
presence of anhydrous sodium sulfate. The mixture was filtered through whatman filter paper no. 1 and $25 \mathrm{ml}$ aliquot of the filtered extract was transferred to $250 \mathrm{ml}$ conical flask to which $30 \mathrm{ml}$ of glacial acetic acid and $2 \mathrm{ml}$ of saturated potassium iodide were added and allowed to stand for $2 \mathrm{~min}$ with occasional stirring. $100 \mathrm{ml}$ of distilled water and $2 \mathrm{ml}$ of $1 \%$ fresh starch solution were added. Flask contents were titrated immediately against 0.1 $\mathrm{N}$ sodium thiosulfate till end point was reached (non-aqueous layer turned to colourless). The blank was run side by side. Peroxide value was determined by following formula:

$$
\begin{array}{r}
\text { (Sample value }- \text { Blank value }) \times \\
\text { Normality of } \mathrm{Na}_{2} \mathrm{~S}_{2} \mathrm{O}_{3} \\
\text { Peroxide value (meq/kg) }=\underset{1000}{\text { Weight of sample }(\mathrm{g})}
\end{array}
$$

\section{Free fatty acid (FFA)}

Weighed sample was taken in a conical flask. To it $20 \mathrm{ml}$ benzene was added and sample was kept for $30 \mathrm{~min}$ for extraction of free fatty acids. $2 \mathrm{ml}$ of extract was taken in flask, $10 \mathrm{ml}$ benzene, $5 \mathrm{ml}$ ethanol and phenolphthalein indicator was added. Titration was carried out against $0.02 \mathrm{~N} \mathrm{KOH}$ till pink colour appeared. FFA was expressed as \% oleic acid.

$\mathrm{ml}$ of alkali $\times$ Normality of alkali $\times 56.1$ Acid value $=$

$$
\text { Weight of sample (g) }
$$

$\% \mathrm{FFA}=$ Acid value $/ 1.99$

\section{Thiobarbituric Acid Reactive Substances (TBARS)}

The extraction method described by Witte et al., (1970) was used with suitable modifications for the determination of TBARS value of cooked chicken patties. $10 \mathrm{~g}$ sample was triturated with $25 \mathrm{ml}$ of precooled
$20 \%$ Trichloroacetic acid (TCA) prepared in 2 $\mathrm{M}$ orthophosphoric acid for $2 \mathrm{~min}$. The content was then transferred to a beaker by rinsing with $25 \mathrm{ml}$ cold distilled water, mixed well and filtered through Whatman filter paper no. 1. Then, $3 \mathrm{ml}$ of TCA extract was mixed with equal volume of 2 - thiobarbituric acid (TBA) reagent $(0.005 \mathrm{M})$ in test tubes and heated at $80^{\circ} \mathrm{C}$ for $35 \mathrm{~min}$. Blank was prepared by mixing $3 \mathrm{ml}$ of $10 \%$ TCA and $3 \mathrm{ml}$ of $0.005 \mathrm{M}$ TBA reagent. Absorbance (O.D) was measured at fixed wavelength of $532 \mathrm{~nm}$ using UV-VIS spectrophotometer.

TBA value (mg malonaldehyde per $\mathrm{Kg}$ of sample $)=$ O.D $\times 5.2$

\section{Texture analysis}

Instrumental texture analysis was conducted using Texture analyser (TMS-PRO, Food Technology Corporation, USA). Sample size of $1.0 \times 1.0 \times 1.0 \mathrm{~cm}$ was subjected to pre-test speed $(30 \mathrm{~mm} / \mathrm{s})$, post-test speed $(100 \mathrm{~mm} / \mathrm{s})$ to a double compression cycle with a load cell of $2500 \mathrm{~N}$. A compression platform of $25 \mathrm{~mm}$ was used as a probe. Texture analysis was performed as per the procedure outlined by Bourne (1978). Hardness was calculated automatically by the preloaded software in the equipment from the force-time plot. It is the height of the force peak $\left(\mathrm{F}_{2}\right)$ on the first compression cycle (first bite is defined as hardness). It is expressed in $\mathrm{N}$ (force). It is defined as maximum force to compress the sample.

\section{Microbiological analysis}

\section{Standard Plate Count (SPC) and Salmonella count}

\section{Sample preparation and serial dilution}

The samples were opened in a laminar flow pre-sterilised by ultra-violet radiation. $10 \mathrm{~g}$ sample was triturated in a pre-sterilised 
mortar using $90 \mathrm{ml}$ sterile $0.1 \%$ peptone water. The sample was homogenised using sterile pestle for $2 \mathrm{~min}$. for uniform distribution and to obtain a $10^{-1}$ dilution of the sample. $1 \mathrm{ml}$ of this diluted solution with a micropipette having a sterile tip into a sterile test tube containing pre-sterilised $0.1 \%$ peptone water for further dilution to a level of $10^{-2}$.

\section{Media preparation and plating}

$23.5 \mathrm{~g}$ of plate count agar obtained from $\mathrm{Hi}-$ Media Laboratories Pvt. Ltd. Mumbai (M091S) was suspended in $1000 \mathrm{ml}$ of distilled water; $23.5 \mathrm{~g}$ of brilliant green agar obtained from Hi-Media laboratories Pvt. Ltd. Mumbai (M091S) was suspended in $1000 \mathrm{ml}$ of distilled water. It was boiled to dissolve the medium completely. It was sterilised at $15 \mathrm{psi}\left(121^{\circ} \mathrm{C}\right)$ for $15 \mathrm{~min}$. The pour plate method was followed for enumeration of bacterial colonies. About 20 $\mathrm{ml}$ of sterilised molten media kept at $45 \pm 2{ }^{\circ} \mathrm{C}$ was inoculated aseptically to each duplicate set of petri plates with $1 \mathrm{ml}$ aliquot. These were gently stirred for uniform distribution of the aliquots. The plates were allowed to stand for some time till the agar solidified. The plates were then inverted and incubated at $35 \pm 2^{\circ} \mathrm{C}$ for $24 \mathrm{~h}$. Following incubation, the plates showing 30-300 colonies were counted. The average number of colonies were multiplied with the reciprocal of the dilution and expressed as $\log _{10} \mathrm{cfu} / \mathrm{g}$ of sample.

\section{$\beta$-carotene estimation}

The method for estimation of $\beta$-carotene was based on method by Biswas et al., (2011a) with suitable modifications. $1 \mathrm{~g}$ sample was taken and triturated with $20 \mathrm{ml}$ acetone using pestle and mortar in the presence of anhydrous sodium sulfate. The sample was quantitatively transferred in a polypropylene centrifuge tube and held at $4 \pm 1^{\circ} \mathrm{C}$ for $15 \mathrm{~min}$ with occasional stirring. The component so obtained was then centrifuged at $5000 \mathrm{rpm}$ for $10 \mathrm{~min}$ in a refrigerated centrifuge. Supernatant was decanted and separate tube and the sample was re-extracted with $20 \mathrm{ml}$ acetone. Both the supernatant were combined and the passed through the Whatman filter paper no. 42. The absorbance of the extract was determined at $449 \mathrm{~nm}$ wavelength. The concentration of $\beta$-carotene was determined by external standard method substituting respective absorbance in linear regression formula: $\mathrm{y}=0.021 \mathrm{x}-0.005, \mathrm{R}^{2}=0.994$.

\section{Cooking method}

Prior to organoleptic evaluation, the chicken patties were cooked in hot air oven at $180^{\circ} \mathrm{C}$ for 25 minutes to achieve an internal temperature of $80^{\circ} \mathrm{C}$. A container of water was placed inside the oven to maintain high humidity throughout the cooking process. The sides of patties were turned once after an interval of 15 minutes.

\section{Statistical analysis}

The data of frozen products were statistically analyzed and subjected to analysis of variance using completely randomized design (CRD) using the software CPCS-1 (Singh et al., 1991).

\section{Results and Discussion}

\section{Proximate composition of cooked chicken} patties

\section{Moisture}

The average moisture content of control, conventionally packed chicken patties decreased significantly $(\mathrm{p} \leq 0.05)$ from 52.958 to 50.514 per cent at the end of two months of frozen storage. The average moisture content 
of fresh cooked functional chicken patties decreased significantly $(\mathrm{p} \leq 0.05)$ from 55.286 to 52.695 per cent after two months of frozen storage period (Table 1). The average moisture per cent of vacuum packed cooked chicken patties decreased significantly $(\mathrm{p} \leq 0.05)$ from 52.958 to 51.984 per cent in control and from 55.286 to 54.217 per cent in functional chicken patties.

The difference in moisture content upon cooking is also associated with the water holding capacity of the patties. Martino and Zaritzky (1988) reported that the size of ice crystals in frozen beef increased with time when stored under constant frozen temperature which resulted in moisture loss during cooking. The results coincide with the results of Biswas et al., (2011 b) where, a similar $(\mathrm{p} \leq 0.05)$ decrease in moisture content of duck patties during storage period has been reported.

\section{Protein}

The average protein content of conventionally packed control chicken patties increased significantly $(p \leq 0.05)$ from 15.168 to 16.026 per cent at the end of two months frozen storage while that of functional chicken patties increased significantly $(\mathrm{p} \leq 0.05)$ from 14.306 to 14.923 per cent but the increase was non-significant $(\mathrm{p} \leq 0.05)$ with respect to treatment, packaging method and frozen storage periods (Table 2). The average protein content of vacuum packed chicken patties increased significantly $(\mathrm{p} \leq 0.05)$ from 15.168 to 15.898 per cent in control and from 14.306 to 14.818 per cent in functional chicken patties with respect to treatment, packaging method and frozen storage periods. Preety (2010) reported the protein content of cooked chicken patties to have increased from 16.87 to 18.15 in control and from 17.49 to 18.65 in treatment with increase in the frozen storage period.

\section{Fat}

The average fat content of conventionally packed control chicken patties increased significantly $(\mathrm{p} \leq 0.05)$ from 12.319 to 13.112 per cent and that of functional chicken patties increased significantly $(\mathrm{p} \leq 0.05)$ from 12.012 to 13.006 per cent (Table 3 ). The average fat content of vacuum packed chicken patties increased significantly $(\mathrm{p} \leq 0.05)$ from 12.319 to 12.900 per cent in control and from 12.012 to 12.409 per cent in functional chicken patties after two months of frozen storage period.

The fat content was higher in conventionally packed chicken patties is probably due to the concentration effects of moisture loss.

\section{Ash}

The average ash content of conventionally packed control chicken patties increased significantly $(\mathrm{p} \leq 0.05)$ from 2.047 to 2.367 per cent at the end of two months of frozen storage with a significant $(\mathrm{p} \leq 0.05)$ increase with respect to treatment, packaging and frozen storage periods. The average ash content of conventionally packed functional chicken patties increased significantly $(\mathrm{p} \leq 0.05)$ from 2.815 to 3.254 per cent.

The average ash content of vacuum packed chicken patties increased significantly $(p \leq 0.05)$ from 2.047 to 2.314 per cent in control and from 2.815 to 3.111 per cent in functional chicken patties after two months of frozen storage period (Table 4).

Verma et al., (2015) have mentioned an increase in ash content with an increase in the treatment levels. According to Thind et al., (2006), the increase in ash content might be attributed to the decrease of moisture content of cooked chicken patties with increase in frozen storage period. 
Table.1 Effect of packaging methods on the moisture content of cooked chicken patties during frozen storage $(n=3)$

\begin{tabular}{|c|c|c|c|c|}
\hline \multirow{2}{*}{$\begin{array}{c}\text { Storage Period } \\
\text { (Days) }\end{array}$} & \multicolumn{2}{|c|}{ Conventional packaging } & \multicolumn{2}{c|}{ Vacuum packaging } \\
\cline { 2 - 5 } & Control & Functional & Control & Functional \\
\hline 0 & $52.958 \pm 0.098$ & $55.286 \pm 0.065$ & $52.958 \pm 0.098$ & $55.286 \pm 0.065$ \\
\hline 15 & $52.071 \pm 0.064$ & $54.622 \pm 0.052$ & $52.819 \pm 0.024$ & $55.054 \pm 0.066$ \\
\hline 30 & $51.519 \pm 0.065$ & $53.413 \pm 0.017$ & $52.498 \pm 0.076$ & $55.002 \pm 0.123$ \\
\hline 45 & $50.938 \pm 0.060$ & $52.957 \pm 0.081$ & $52.017 \pm 0.078$ & $54.649 \pm 0.052$ \\
\hline 60 & $50.514 \pm 0.016$ & $52.695 \pm 0.119$ & $51.984 \pm 0.073$ & $54.217 \pm 0.030$ \\
\hline
\end{tabular}

C.D. $(\mathrm{p} \leq 0.05)$ Treatment: 0.043 Packaging: 0.043 Storage: 0.068 Treatment $\times$ Packaging: 0.601 Treatment $\times$ Storage: NS Packaging $\times$ Storage: 0.096 Treatment $\times$ Packaging $\times$ Storage: 0.136

Table.2 Effect of packaging methods on the protein content of cooked chicken patties during frozen storage $(n=3)$

\begin{tabular}{|c|c|c|c|c|}
\hline $\begin{array}{c}\text { Storage Period } \\
\text { (Days) }\end{array}$ & \multicolumn{2}{|c|}{ Conventional packaging } & \multicolumn{2}{c|}{ Vacuum packaging } \\
\cline { 2 - 5 } & Control & Functional & Control & Functional \\
\hline 0 & $15.168 \pm 0.069$ & $14.306 \pm 0.024$ & $15.168 \pm 0.069$ & $14.306 \pm 0.024$ \\
\hline 15 & $15.304 \pm 0.058$ & $14.598 \pm 0.054$ & $15.229 \pm 0.020$ & $14.462 \pm 0.026$ \\
\hline 30 & $15.661 \pm 0.063$ & $14.762 \pm 0.066$ & $15.584 \pm 0.062$ & $14.518 \pm 0.023$ \\
\hline 45 & $15.981 \pm 0.077$ & $14.879 \pm 0.067$ & $15.792 \pm 0.039$ & $14.692 \pm 0.005$ \\
\hline 60 & $16.026 \pm 0.119$ & $14.923 \pm 0.037$ & $15.898 \pm 0.062$ & $14.818 \pm 0.051$ \\
\hline
\end{tabular}

C.D. $(\mathrm{p} \leq 0.05)$ Treatment: 0.030 Packaging: 0.030 Storage: 0.047 Treatment $\times$ Packaging: NS Treatment $\times$ Storage: 0.067 Packaging $\times$ Storage: 0.067 Treatment $\times$ Packaging $\times$ Storage: NS

Table.3 Effect of packaging methods on the fat content of cooked chicken patties during frozen storage $(n=3)$

\begin{tabular}{|c|c|c|c|c|}
\hline \multirow{2}{*}{$\begin{array}{c}\text { Storage } \\
\text { Period (Days) }\end{array}$} & \multicolumn{2}{|c|}{ Conventional packaging } & \multicolumn{2}{c|}{ Vacuum packaging } \\
\cline { 2 - 5 } & Control & Functional & Control & Functional \\
\hline 0 & $12.319 \pm 0.025$ & $12.012 \pm 0.013$ & $12.319 \pm 0.025$ & $12.012 \pm 0.013$ \\
\hline 15 & $12.364 \pm 0.007$ & $12.284 \pm 0.027$ & $12.339 \pm 0.014$ & $12.063 \pm 0.004$ \\
\hline 30 & $12.861 \pm 0.018$ & $12.632 \pm 0.027$ & $12.601 \pm 0.017$ & $12.173 \pm 0.004$ \\
\hline 45 & $13.016 \pm 0.036$ & $12.899 \pm 0.014$ & $12.705 \pm 0.004$ & $12.303 \pm 0.010$ \\
\hline 60 & $13.112 \pm 0.051$ & $13.006 \pm 0.010$ & $12.900 \pm 0.013$ & $12.409 \pm 0.002$ \\
\hline
\end{tabular}

C.D. $(\mathrm{p} \leq 0.05)$ Treatment: 0.011 Packaging: 0.011 Storage: 0.017 Treatment $\times$ Packaging: 0.015 Treatment $\times$ Storage: 0.024 Packaging $\times$ Storage: 0.024 Treatment $\times$ Packaging $\times$ Storage: 0.333

Table.4 Effect of packaging methods on the ash content of cooked chicken patties during frozen storage $(n=3)$

\begin{tabular}{|c|c|c|c|c|}
\hline $\begin{array}{c}\text { Storage Period } \\
\text { (Days) }\end{array}$ & \multicolumn{2}{|c|}{ Conventional Packaging } & \multicolumn{2}{c|}{ Vacuum packaging } \\
\cline { 2 - 5 } & Control & Functional & Control & Functional \\
\hline 0 & $2.047 \pm 0.004$ & $2.815 \pm 0.006$ & $2.047 \pm 0.004$ & $2.815 \pm 0.006$ \\
\hline 15 & $2.108 \pm 0.005$ & $3.165 \pm 0.008$ & $2.088 \pm 0.006$ & $2.956 \pm 0.016$ \\
\hline 30 & $2.199 \pm 0.007$ & $3.198 \pm 0.016$ & $2.149 \pm 0.007$ & $3.049 \pm 0.007$ \\
\hline 45 & $2.304 \pm 0.006$ & $3.221 \pm 0.003$ & $2.262 \pm 0.008$ & $3.108 \pm 0.007$ \\
\hline 60 & $2.367 \pm 0.005$ & $3.254 \pm 0.008$ & $2.314 \pm 0.007$ & $3.111 \pm 0.015$ \\
\hline
\end{tabular}

C.D. $(\mathrm{p} \leq 0.05)$ Treatment: 0.005 Packaging: 0.005 Storage: 0.009 Treatment $\times$ Packaging: 0.008 Treatment $\times$ Storage: 0.012 Packaging $\times$ Storage: 0.012 Treatment $\times$ Packaging $\times$ Storage: 0.017 
Table.5 Effect of packaging methods on the crude fiber content of cooked chicken patties during frozen storage $(n=3)$

\begin{tabular}{|c|c|c|c|c|}
\hline \multirow{2}{*}{$\begin{array}{c}\text { Storage Period } \\
\text { (Days) }\end{array}$} & \multicolumn{2}{|c|}{ Conventional Packaging } & \multicolumn{2}{c|}{ Vacuum packaging } \\
\cline { 2 - 5 } & Control & Functional & Control & Functional \\
\hline 0 & $0.317 \pm 0.004$ & $1.843 \pm 0.014$ & $0.317 \pm 0.004$ & $1.843 \pm 0.014$ \\
\hline 15 & $0.382 \pm 0.006$ & $1.921 \pm 0.005$ & $0.351 \pm 0.007$ & $1.880 \pm 0.014$ \\
\hline 30 & $0.458 \pm 0.013$ & $1.983 \pm 0.013$ & $0.427 \pm 0.005$ & $1.921 \pm 0.010$ \\
\hline 45 & $0.504 \pm 0.007$ & $2.065 \pm 0.012$ & $0.443 \pm 0.006$ & $1.964 \pm 0.007$ \\
\hline 60 & $0.521 \pm 0.004$ & $2.123 \pm 0.012$ & $0.458 \pm 0.007$ & $2.013 \pm 0.013$ \\
\hline
\end{tabular}

C.D. $(\mathrm{p} \leq 0.05)$ Treatment: 0.005 Packaging: 0.005 Storage: 0.008 Treatment $\times$ Packaging: NS Treatment $\times$ Storage: 0.011 Packaging $\times$ Storage: 0.011 Treatment $\times$ Packaging $\times$ Storage: 0.016

Table.6 Effect of packaging methods on the free fatty acid (\% oleic acid) of cooked chicken patties during frozen storage $(\mathrm{n}=3)$

\begin{tabular}{|c|c|c|c|c|}
\hline $\begin{array}{c}\text { Storage Period } \\
\text { (Days) }\end{array}$ & \multicolumn{2}{|c|}{ Conventional packaging } & \multicolumn{2}{c|}{ Vacuum packaging } \\
\cline { 2 - 5 } & Control & Functional & Control & Functional \\
\hline 0 & $0.017 \pm 0.000$ & $0.011 \pm 0.000$ & $0.017 \pm 0.000$ & $0.011 \pm 0.000$ \\
\hline 15 & $0.128 \pm 0.000$ & $0.108 \pm 0.001$ & $0.125 \pm 0.005$ & $0.078 \pm 0.005$ \\
\hline 30 & $0.182 \pm 0.002$ & $0.168 \pm 0.003$ & $0.137 \pm 0.002$ & $0.112 \pm 0.002$ \\
\hline 45 & $0.299 \pm 0.003$ & $0.210 \pm 0.005$ & $0.160 \pm 0.004$ & $0.142 \pm 0.000$ \\
\hline 60 & $0.315 \pm 0.005$ & $0.215 \pm 0.004$ & $0.165 \pm 0.003$ & $0.150 \pm 0.005$ \\
\hline
\end{tabular}

C.D. $(\mathrm{p} \leq 0.05)$ Treatment: 0.002 Packaging: 0.002 Storage: 0.003 Treatment $\times$ Packaging: 0.002 Treatment $\times$ Storage: 0.004 Packaging $\times$ Storage: 0.004 Treatment $\times$ Packaging $\times$ Storage: 0.005

Table.7 Effect of packaging methods on peroxide value (meq/Kg) of cooked chicken patties during frozen storage $(\mathrm{n}=3)$

\begin{tabular}{|c|c|c|c|c|}
\hline \multirow{2}{*}{$\begin{array}{c}\text { Storage } \\
\text { Period (Days) }\end{array}$} & \multicolumn{2}{|c|}{ Conventional packaging } & \multicolumn{2}{c|}{ Vacuum packaging } \\
\cline { 2 - 5 } & Control & Functional & Control & Functional \\
\hline 0 & $0.104 \pm 0.001$ & $0.102 \pm 0.000$ & $0.104 \pm 0.001$ & $0.102 \pm 0.000$ \\
\hline 15 & $0.294 \pm 0.005$ & $0.256 \pm 0.009$ & $0.116 \pm 0.003$ & $0.118 \pm 0.000$ \\
\hline 30 & $0.407 \pm 0.005$ & $0.358 \pm 0.011$ & $0.242 \pm 0.000$ & $0.207 \pm 0.002$ \\
\hline 45 & $0.508 \pm 0.005$ & $0.411 \pm 0.002$ & $0.365 \pm 0.003$ & $0.318 \pm 0.000$ \\
\hline 60 & $0.519 \pm 0.004$ & $0.439 \pm 0.005$ & $0.422 \pm 0.003$ & $0.358 \pm 0.009$ \\
\hline
\end{tabular}

C.D. $(\mathrm{p} \leq 0.05)$ Treatment: 0.002 Packaging: 0.002 Storage: 0.004 Treatment $\times$ Packaging: 0.003 Treatment $\times$ Storage: 0.005 Packaging $\times$ Storage: 0.005 Treatment $\times$ Packaging $\times$ Storage: 0.008

Table.8 Effect of packaging methods on thiobarbituric acid (TBA) value of cooked chicken patties during frozen storage $(n=3)$

\begin{tabular}{|c|c|c|c|c|}
\hline \multirow{2}{*}{$\begin{array}{c}\text { Storage } \\
\text { Period (Days) }\end{array}$} & \multicolumn{2}{|c|}{ Conventional packaging } & \multicolumn{2}{c|}{ Vacuum packaging } \\
\cline { 2 - 5 } & Control & Functional & Control & Functional \\
\hline 0 & $0.026 \pm 0.002$ & $0.017 \pm 0.002$ & $0.026 \pm 0.002$ & $0.017 \pm 0.002$ \\
\hline 15 & $0.087 \pm 0.003$ & $0.052 \pm 0.007$ & $0.041 \pm 0.004$ & $0.026 \pm 0.005$ \\
\hline 30 & $0.156 \pm 0.005$ & $0.104 \pm 0.000$ & $0.093 \pm 0.003$ & $0.104 \pm 0.000$ \\
\hline 45 & $0.209 \pm 0.010$ & $0.176 \pm 0.003$ & $0.152 \pm 0.000$ & $0.129 \pm 0.000$ \\
\hline 60 & $0.368 \pm 0.005$ & $0.228 \pm 0.007$ & $0.209 \pm 0.006$ & $0.152 \pm 0.006$ \\
\hline
\end{tabular}

C.D. $(\mathrm{p} \leq 0.05)$ Treatment: 0.002 Packaging: 0.002 Storage: 0.003 Treatment $\times$ Packaging: 0.003 Treatment $\times$ Storage: 0.005 Packaging $\times$ Storage: 0.005 Treatment $\times$ Packaging $\times$ Storage: 0.007 
Table.9 Effect of packaging methods on $\beta$-carotene content $(\mu \mathrm{g} / \mathrm{g})$ of cooked chicken patties during frozen storage $(n=3)$

\begin{tabular}{|c|c|c|c|c|}
\hline $\begin{array}{c}\text { Storage Period } \\
\text { (Days) }\end{array}$ & \multicolumn{2}{|c|}{ Conventional packaging } & \multicolumn{2}{c|}{ Vacuum packaging } \\
\cline { 2 - 5 } & Control & Functional & Control & Functional \\
\hline 0 & Traces & $2.458 \pm 0.014$ & Traces & $2.458 \pm 0.014$ \\
\hline 15 & Traces & $2.446 \pm 0.018$ & Traces & $2.446 \pm 0.024$ \\
\hline 30 & Traces & $2.391 \pm 0.007$ & Traces & $2.441 \pm 0.000$ \\
\hline 45 & Traces & $2.326 \pm 0.013$ & Traces & $2.398 \pm 0.006$ \\
\hline 60 & Traces & $2.278 \pm 0.009$ & Traces & $2.396 \pm 0.004$ \\
\hline
\end{tabular}

C.D. $(\mathrm{p} \leq 0.05)$ Treatment: 0.005 Packaging: 0.005 Storage: 0.007 Treatment $\times$ Packaging: 0.007 Treatment $\times$ Storage: 0.011 Packaging $\times$ Storage: 0.011 Treatment $\times$ Packaging $\times$ Storage: 0.015

Table.10 Effect of packaging methods on standard plate count (SPC) (log cfu/g) of cooked chicken patties during frozen storage $(n=3)$

\begin{tabular}{|c|c|c|c|c|}
\hline \multirow{2}{*}{$\begin{array}{c}\text { Storage Period } \\
\text { (Days) }\end{array}$} & \multicolumn{2}{|c|}{ Conventional packaging } & \multicolumn{2}{c|}{ Vacuum packaging } \\
\cline { 2 - 5 } & Control & Functional & Control & Functional \\
\hline 0 & $2.996 \pm 0.000$ & $2.996 \pm 0.000$ & $2.996 \pm 0.000$ & $2.996 \pm 0.000$ \\
\hline 15 & $2.996 \pm 0.000$ & $2.996 \pm 0.000$ & $2.996 \pm 0.000$ & $2.996 \pm 0.000$ \\
\hline 30 & $2.996 \pm 0.000$ & $2.996 \pm 0.000$ & $2.996 \pm 0.000$ & $2.996 \pm 0.000$ \\
\hline 45 & $2.996 \pm 0.000$ & $2.996 \pm 0.000$ & $2.996 \pm 0.000$ & $2.996 \pm 0.000$ \\
\hline 60 & $3.824 \pm 0.234$ & $3.458 \pm 0.400$ & $2.996 \pm 0.000$ & $2.996 \pm 0.000$ \\
\hline
\end{tabular}

C.D. $(\mathrm{p} \leq 0.05)$ Treatment: NS Packaging: 0.054 Storage: 0.085 Treatment $\times$ Packaging: NS Treatment $\times$ Storage: NS Packaging $\times$ Storage: 0.121 Treatment $\times$ Packaging $\times$ Storage: NS

Table.11 Effect of packaging methods on salmonella count (log cfu/g) of cooked chicken patties during frozen storage $(\mathrm{n}=3)$

\begin{tabular}{|c|c|c|c|c|}
\hline \multirow{2}{*}{$\begin{array}{c}\text { Storage Period } \\
\text { (Days) }\end{array}$} & \multicolumn{2}{|c|}{ Conventional packaging } & \multicolumn{2}{c|}{ Vacuum packaging } \\
\cline { 2 - 5 } & Control & Functional & Control & Functional \\
\hline 0 & ND & ND & ND & ND \\
\hline 15 & ND & ND & ND & ND \\
\hline 30 & ND & ND & ND & ND \\
\hline 45 & ND & ND & ND & ND \\
\hline 60 & ND & ND & ND & ND \\
\hline
\end{tabular}

*ND: Not Detected

Table.12 Effect of packaging methods on hardness $(\mathrm{N})$ of cooked chicken patties during frozen storage $(n=3)$

\begin{tabular}{|c|c|c|c|c|}
\hline \multirow{2}{*}{$\begin{array}{c}\text { Storage Period } \\
\text { (Days) }\end{array}$} & \multicolumn{2}{|c|}{ Conventional packaging } & \multicolumn{2}{c|}{ Vacuum packaging } \\
\cline { 2 - 5 } & Control & Functional & Control & Functional \\
\hline 0 & $22.395 \pm 0.105$ & $24.875 \pm 0.019$ & $22.395 \pm 0.105$ & $24.875 \pm 0.019$ \\
\hline 15 & $23.195 \pm 0.022$ & $26.153 \pm 0.040$ & $23.568 \pm 0.020$ & $25.249 \pm 0.027$ \\
\hline 30 & $24.212 \pm 0.019$ & $27.408 \pm 0.013$ & $24.456 \pm 0.040$ & $25.581 \pm 0.065$ \\
\hline 45 & $25.700 \pm 0.037$ & $27.913 \pm 0.033$ & $24.854 \pm 0.025$ & $26.852 \pm 0.030$ \\
\hline 60 & $26.010 \pm 0.066$ & $28.205 \pm 0.042$ & $25.222 \pm 0.022$ & $27.198 \pm 0.021$ \\
\hline
\end{tabular}

C.D. $(\mathrm{p} \leq 0.05)$ Treatment: 0.024 Packaging: 0.024 Storage: 0.038 Treatment $\times$ Packaging: 0.034 Treatment $\times$ Storage: 0.054 Packaging $\times$ Storage: 0.054 Treatment $\times$ Packaging $\times$ Storage: 0.076 


\section{Crude fiber}

The average crude fibre content of conventionally packed control chicken patties increased significantly $(\mathrm{p} \leq 0.05)$ from 0.317 to 0.521 per cent at the end of two months of frozen storage period and that of functional chicken patties increased significantly $(p \leq 0.05)$ from 1.843 to 2.123 per cent at the end of two months of frozen storage period. The average fibre content of vacuum packed, cooked chicken patties increased significantly $(\mathrm{p} \leq 0.05)$ from 0.317 to 0.458 per cent in control and from 1.843 to 2.013 per cent in functional chicken patties containing dried apricots and dried citrus fruit residue after two months of frozen storage period (Table 5).

The increase of fibre content in chicken patties with increase in frozen storage time could be due to decrease in moisture content of the chicken patties with frozen storage. According to Thind et al., (2006), increase in fibre content might be attributed to decrease of moisture content of cooked chicken patties with increase in frozen storage period.

\section{Free Fatty Acid (FFA)}

The average free fatty acid content of conventionally packed control chicken patties increased significantly $(p \leq 0.05)$ from 0.017 to 0.315 per cent at the end of two months frozen storage period versus the average free fatty acid content of cooked functional chicken patties increasing significantly $(p \leq 0.05)$ from 0.011 to 0.215 per cent (Table 6). The average free fatty acid content of vacuum packed cooked chicken patties increased significantly $(\mathrm{p} \leq 0.05)$ from 0.017 to 0.165 per cent in control and increased significantly from 0.011 to 0.150 per cent in functional chicken patties.

Modi et al., (2006) have attributed an increase in FFA values in different meat products to lipase activity during storage. Bhat and Pathak (2012) reported similar trend for refrigerated storage of mutton where FFA values ranged from $0.015 \pm 0.001$ to $0.046 \pm 0.001$.

\section{Peroxide value}

The average peroxide value of conventionally packed, cooked control chicken patties increased significantly $(\mathrm{p} \leq 0.05)$ from 0.104 to $0.519(\mathrm{meq} / \mathrm{Kg})$ at the end of two months of frozen storage period. The average peroxide value of fresh, cooked, functional chicken patties containing dried apricots and dried citrus fruit residue increased significantly $(p \leq 0.05)$ from 0.102 to $0.439(\mathrm{meq} / \mathrm{Kg})$. The average peroxide value of vacuum packed, cooked chicken patties increased significantly $(p \leq 0.05)$ from 0.104 to $0.422(\mathrm{meq} / \mathrm{Kg})$ in control and significantly $(\mathrm{p} \leq 0.05)$ from 0.102 to $0.358(\mathrm{meq} / \mathrm{Kg})$ in functional chicken patties after two months of frozen storage period. All the samples of functional chicken patties had significantly $(\mathrm{P}<0.05)$ lower peroxide value as compared to control (Table 7).

The mechanism of protection against lipid (as measured by peroxide value) may be partly due to the flavonoids present in dried citrus fruit residue, which are potential antioxidants and exhibit a scavenging and inhibiting effect against the production and initiation of free radicals, superoxide anions and lipid peroxy radicals and partly due to the carotenoids of dried apricots, which function as antioxidants by terminating free radical chain reaction (Kumar et al., 2013). The lower peroxide values of vacuum packed patties were evidently due to absence of air.

\section{Thiobarbituric acid value}

The average thiobarbituric acid (TBA) value of conventionally packed control chicken 
patties and vacuum packed functional chicken patties increased significantly $(\mathrm{p} \leq 0.05)$ from 0.026 to $0.368(\mathrm{mg} / \mathrm{Kg})$ and from 0.026 to 0.209 respectively at the end of two months of frozen storage period. The average TBA value of conventionally packed functional chicken patties increased significantly $(\mathrm{p} \leq 0.05)$ from 0.017 to $0.228(\mathrm{mg} / \mathrm{Kg})$ and that of vacuum packed functional chicken patties increased significantly $(p \leq 0.05)$ from 0.017 to 0.152 $(\mathrm{mg} / \mathrm{Kg})$ after two months of frozen storage period (Table 8).

The functional chicken patties showed lower TBA values, possibly due to the antioxidative character of dried apricots and dried citrus fruit residue. Sáyago-Ayerdi et al., (2009) reported an increase in TBA value of chicken patties stored frozen for six months.

Devatkal et al., (2010) have reported a significant decrease in oxidation of raw ground goat meat on addition of kinnow rind peel (KRP), highlighting the anti-oxidative properties of KRP. Besides, they also reported an increasing trend of TBARS value with storage time. Singh et al., (2014) have also reported a similar increase in the TBA values of stored chicken meat emulsion. As suggested by Al-Kahtani et al., (1996), meat products with less than $3 \mathrm{mg}$ MDA/kg sample can be regarded as well preserved with respect to the oxidative changes.

\section{$\beta$-carotene}

$\beta$-carotene was estimated to be present in traces in the control chicken patties.

The average $\beta$-carotene content of conventionally packed, cooked functional chicken patties containing dried apricots and dried citrus fruit residue decreased significantly $(\mathrm{p} \leq 0.05)$ from 2.458 to 2.278 $\mu \mathrm{g} / \mathrm{g}$ while average $\beta$-carotene content in vacuum packed, cooked functional chicken patties containing dried apricots and dried citrus fruit residue decreased significantly $(\mathrm{p} \leq 0.05)$ from 2.458 to $2.396 \mu \mathrm{g} / \mathrm{g}$ (Table 9 ).

Evidently, the loss of $\beta$-carotene was significantly $\quad(p \leq 0.05) \quad$ higher in conventionally packed functional chicken patties than those packed under vacuum primarily, because of sensitivity of carotenoids to oxidation and other products of oxidation. Overall losses of $\beta$-carotene in chicken patties could have been derived from a combination of factors such as oxidation, exposure to light, loss of fat during cooking and other temperature fluctuations.

Biswas et al., (2011 a) studied the amount of $\beta$-carotene in case of cooked chicken meat nuggets containing carrot. While there was no determination of $\beta$-carotene in case of control chicken meat nuggets, the $\beta$-carotene level ranged up to $5.65 \mu \mathrm{g} / \mathrm{g}$ in case of chicken meat nuggets containing carrot. Bhosale et al., (2011) reported the $\beta$-carotene content of chicken meat nuggets containing mashed sweet potato to range up to $5.11(\mu \mathrm{g} / \mathrm{g})$.

\section{Microbiological analysis of chicken patties}

The average SPC of fresh conventionally packed uncooked chicken patties (after heating at $180^{\circ} \mathrm{C}$ for $10 \mathrm{~min}$ ) was $2.996 \mathrm{log}$ $\mathrm{cfu} / \mathrm{g}$ in control and $2.996 \mathrm{log} \mathrm{cfu} / \mathrm{g}$ in functional chicken patties containing dried apricots and dried citrus fruit residue. SPC values of patties increased significantly $(\mathrm{p} \leq 0.05)$ to $3.824 \log \mathrm{cfu} / \mathrm{g}$ and $3.458 \mathrm{log}$ $\mathrm{cfu} / \mathrm{g}$ respectively after two months of frozen storage period. The average SPC of vacuum packed, raw control and functional chicken patties remained unchanged at $2.996 \mathrm{log} \mathrm{cfu} / \mathrm{g}$ at the end of two months of frozen storage ($20 \pm 2^{\circ} \mathrm{C}$ ) period. The results were nonsignificant $(\mathrm{p} \leq 0.05)$ with respect to treatment, packaging and frozen storage period (Table $10)$. 
The marginal increase in the microbial count of patties could be attributed to the contamination during handling i.e. moulding of patties from emulsion. The microbial count of vacuum packed patties was less than conventionally packed patties due to the absence of essential oxygen which supports the microbial growth. The microbial growth at the end of storage period could have been initiated due to the temperature fluctuations caused during storage. The presence of air in the conventionally packed patties could have promoted this growth.

\section{Hardness of chicken patties}

The average hardness of conventionally packed control chicken patties increased significantly $(\mathrm{p} \leq 0.05)$ from 22.395 to 26.010 $(\mathrm{N})$ while the average hardness of functional chicken patties increased significantly $(p \leq 0.05)$ from 24.875 to $28.205(\mathrm{~N})$.The average hardness of vacuum packed, control chicken patties increased significantly $(\mathrm{p} \leq 0.05)$ from 22.395 to $25.222(\mathrm{~N})$ and the average hardness of functional chicken patties increased significantly $(\mathrm{p} \leq 0.05)$ from 24.875 to $27.198(\mathrm{~N})$ at the end of two months of frozen storage period $\left(-20 \pm 2^{\circ} \mathrm{C}\right)$.

The slightly higher levels of hardness in functional chicken patties than control might be due to the lower fat content of these patties. Santhi and Kalaikannan (2014) reported increasing hardness of chicken nuggets with treatment and Garcia et al., (2002) reported that hardness of fermented sausages increased from 207.14 to 315.54 $\left(\mathrm{N} / \mathrm{cm}^{2}\right)$ with increase in level of addition of wheat fibre.

As per the results of the present study, it could be concluded that chicken meat patties containing functional ingredients had enhanced nutritional composition with significant increase in fiber and $\beta$-carotene contents and lower levels of peroxide values, free fatty acids and TBA values. Chicken patties packed under vacuum had higher storage stability with respect to proximate composition and chemical parameters, compared to those packed conventionally. Chicken patties containing dried apricots and dried citrus fruit residue were acceptable throughout the frozen storage period. The present work can be further experimented and expanded to pilot scale production level followed by test marketing of frozen functional chicken meat patties containing dried apricots and dried citrus fruit residue before their commercial launch.

\section{References}

Al-Kahtani H A, Abu-Tarboush H M, Bajaber A S, Atia M, Abou-Arab A A and ElMojaddidi M A (1996) Chemical changes after irradiation and post-irradiation in tilapia and Spanish mackerel. J Food Sci 61:729-33.

AOAC (1995) Official methods of analysis (16th edition) Association of Official Analytical Chemists, Washington, D.C.

Archive

India (2011)http://www.archive.india.gov.in/sect ors/agriculture/index.php?id=15

Bhat Z F and Pathak V (2012) Quality evaluation of mutton Harrisa during one week refrigerated storage. J Food Sci Technol 49:620-25.

Bhosale S S, Biswas A K, Sahoo J, Chatli M K, Sharma D K and Sikka S S (2011) Quality evaluation of functional chicken nuggets incorporated with ground carrot and mashed sweet potato. Food Sci Technol Int 17:233-9.

Biswas A K, Sahoo J and Chatli M K (2011 a) A simple UV-Vis spectrophotometric method for determination of $\mathrm{b}$-carotene content in raw carrot, sweet potato and supplemented chicken meat nuggets: $L W T-$ Food Sci and Technol 44:1809-13.

Biswas S, Chakraborty A, Patra G and Dhargupta A (2011 b) Quality and acceptability of duck patties stored at ambient and 
refrigeration temperatures. Int $J$ Livestock Prod 1:1-6.

Bourne M C (1978) Texture profile analysis. Food Technol 33:62-66.

Devatkal S K and Naveena B M (2010) Effect of salt, kinnow and pomegranate fruit byproduct powders on colour and oxidative stability of raw ground goat meat during refrigerated storage. Meat Sci 85:306-11.

FAOSTAT (2013) www.faostat.com

Garcia M L, Dominguez R, Galvez M D, Casas C and Selgas M D (2002) Utilization of cereal and fruit fibres in low fat dry fermented sausages. Meat Sci 60:227-36.

Koniecko R (1979) Handbook for meat chemists. pp 53-55. Avery Publishing Group Inc. Wayne, New Jersy.

Kumar P, Kumar S, Tripathi M K, Mehta N, Ranjan R, Bhat Z F and Singh P K (2013) Flavonoids in the development of functional meat products: A review. Vet World 6:573-78.

Livestock census http://dahd.nic.in/dahd/statistics/livestockcensus.aspx

Martino M N and Zaritzky N E (1988) Ice crystal size modifications during frozen beef storage. J Food Sci 53:1631-37.

Modi V K, Sachindra N N, Sathisha A D, Mahendrakar N S and Rao D N (2006) Changes in quality of chicken curry during frozen storage. J Muscle Foods 17:141-54.

MOSPI (2015) http://mospi.nic.in/Mospi_ New/ upload/SYB2015/CH-10-LIVE-

STOCK\%20AND

$\%$ 20FISHERIES/Livestock_and_fisheries_ writeup.pdf accessed 25 july

National Meat and Poultry Processing Board (2014) http://nmppb.gov.in/PAGE/ Meat\%
20and\%20Meat\%20Products\%20Sector/Me at $\% 20$ and $\% 20$ Meat $\% 20$ Products $\% 20$ Sector .htm.

Preety (2010) Development of chicken meat patties incorporating functional ingredients. M.Sc. thesis, Punjab Agricultural University, Ludhiana, India.

Santhi D and Kalaikannan A (2014) The effect of the addition of oat flour in low-fat chicken nuggets. J Nutr Food Sci 4:260-64.

Sáyago-Ayerdi S G, Brenes A, Viveros A and Goñi I (2009) Antioxidative effect of dietary grape pomace concentrate on lipid oxidation of chilled and long-term frozen stored chicken patties. Meat Sci 83:528-33.

Singh P, Sahoo J, Chatli M K and Biswas A K (2014) Shelf life evaluation of raw chicken meat emulsion incorporated with clove powder, ginger and garlic paste as natural preservatives at refrigerated storage $\left(4 \pm 1^{\circ} \mathrm{C}\right)$. Int Food Research J 2:1363-73.

Singh S, Bansal M L, Singh T P and Kumar R (1991) Statistical methods for research worker. Pp 310-17 Kalyani Publishers, New Delhi.

Thind S S, Gupta P and Padda G S (2006) Incorporation of wheat and corn germs as extenders in chicken meat patties. Beverage Food World 33:54-55.

Verma A K, Chatli M K, Kumar D, Kumar P and Mehta N (2015) Efficacy of sweet potato powder and added water as fat replacer on the quality attributes of low-fat pork patties. Asian Aust J Anim Sci 28:252-59.

Witte V C, Krause G F and Bailey M E (1970) A new extraction method for determining 2Thiobarbituric acid values of pork, beef during storage. J Food Sci 35:582-85.

\section{How to cite this article:}

Shruti Sharma, Himanshu Prabhakar, S.S. Thind, Manish Chatli and Amarjeet Kaur. 2017. Evaluation of the Effect of Incorporation of Functional Ingredients on the Shelf Life of Chicken Patties Using Different Packaging Conditions during Frozen Storage. Int.J.Curr.Microbiol.App.Sci. 6(11): 2797-2809. doi: https://doi.org/10.20546/ijcmas.2017.611.330 